Scientia Marina 71(4)

December 2007, 765-773, Barcelona (Spain)

ISSN: 0214-8358

\title{
Trawl catch composition during different fishing intensity periods in two Mediterranean demersal fishing grounds
}

\author{
PILAR SÁNCHEZ ${ }^{1}$, PAOLO SARTOR ${ }^{2}$, LAURA RECASENS ${ }^{1}$, ALESSANDRO LIGAS ${ }^{2}$, \\ JAVIER MARTIN ${ }^{3}$, STEFANO DE RANIERI ${ }^{2}$ and MONTSERRAT DEMESTRE ${ }^{1}$ \\ ${ }^{1}$ Institut de Ciències del Mar-CSIC, P. Marítim de la Barceloneta, 37-49, 08003 Barcelona, Spain. \\ E-mail: pilar@icm.csic.es \\ ${ }^{2}$ Centro Interuniversitario di Biologia Marina ed Ecologia Applicata, Livorno, Italy. \\ ${ }^{3}$ Mediterraneo Servicios Marinos, Antigua Estación Marítima, Alacant, Spain.
}

SUMMARY: The study was carried out in two fishing grounds on the Mediterranean continental shelf: one in the Adriatic Sea and one in the Catalan Sea. Samplings on board otter trawlers were performed from November 2002 to December 2003 in the Catalan Sea and from February 2003 to January 2004 in the Adriatic Sea. The Adriatic fishing ground was affected by high fishing intensity from January to June, while the Catalan area was highly exploited from September to February. Fishing activity in the Adriatic area was closed for 45 days, and 62 days in the Catalan area; both periods were in summer. Totals of 92 and 88 species were collected in the Adriatic and Catalan fishing grounds respectively. The species composition of the retained and discarded fractions showed close agreement between the two areas. Mullus barbatus showed very low discard rates in both areas, as well as Loligo vulgaris in the Catalan Sea and Merluccius merluccius in the Adriatic Sea. In both fishing grounds Squilla mantis showed high catch rates with low discards, except in March in the Catalan area. In the Adriatic Sea Liocarcinus depurator was characterized by large discard fractions. In both fishing grounds the retained fraction was slightly higher in the high fishing intensity periods than in the low intensity ones (Adriatic Sea: 0.613 vs 0.524; Catalan Sea: 0.597 vs 0.539$)$, even though the Kruskall Wallis test revealed significant differences $(p<0.05)$ only for the Adriatic Sea.

Keywords: discards, fishing closure, fishing effort, western and central Mediterranean.

RESUMEN: COMPOSICIÓN DE LA CAPTURA DE ARRASTRE EN PERIODOS CON DIFERENTE INTENSIDAD DE PESCA EN DOS CALADEROS DEL MEDITERRÁNEO. - Este estudio se realizó en dos caladeros de la plataforma continental: uno en el mar Adriático y el otro en el Catalán. El muestreo se llevo a cabo a bordo de arrastreros comerciales desde noviembre 2002 a diciembre 2003 en el mar Catalán y desde febrero 2003 hasta enero 2004 en el Adriático. En este último caladero se detectó un periodo de alta intensidad de pesca que abarca desde enero a junio, mientras que la explotación más alta se produce de septiembre a febrero en el mar Catalán. En el Adriático se realiza una veda estival de 45 días, mientras que en la zona catalana el paro es de 62 días, también en verano. Se recolectó un total de 92 y 88 especies en los caladeros del Adriático y del mar Catalán, respectivamente. La composición específica de las fracciones retenida y descartada fue similar en ambas áreas. La proporción de descarte de Mullus barbatus fue muy baja en las dos áreas, así como la de Loligo vulgaris en el mar Catalán y Merluccius merluccius en el Adriático. En ambos caladeros, Squilla mantis mostró proporciones de captura altas con descartes bajos, excepto en marzo en el área catalana. Liocarcinus depurator se caracterizó por proporciones de descarte grandes en Adriático. La proporción comercializada fue ligeramente mayor en las épocas de alta intensidad de pesca en ambos caladeros (Adriático: 0.613 vs 0.524; Catalán: 0.597 vs 0.539). Sin embargo, únicamente se hallaron diferencias significativas $(\mathrm{p}<0.05)$ en el caso del caladero adriático.

Palabras clave: descartes, veda, esfuerzo pesquero, Mediterráneo Central y Occidental. 


\section{INTRODUCTION}

It is obvious that all fishing activities not only have a direct impact on target species and bycatch, but also on the whole marine ecosystem. Fishing activity affects population structure, habitats, biodiversity and productivity (Rice and Gislason, 1996; Jennings and Kaiser, 1998; Bas, 2005). In particular, bottom towed gears, such as otter trawlers, have a large impact on the benthic habitat, mainly epifauna and the communities that inhabit the upper sediment layers (Kaiser and De Groot, 1999).

In this context, an increasing amount of scientific effort has been devoted in recent years to studying the effects of fisheries on the ecosystem (Alverson et al., 1994; Jennings and Kaiser, 1998; Rochet et al., 2002, Kellecher, 2005). By applying an analytical design Greenstreet and Rogers (2006) found that variation in fishing effort is the main cause of differences in the size structure of the groundfish assemblage.

Some papers have touched on trawl discards in the Mediterranean Sea, mainly focusing on bathymetric discard differences (Carbonell et al., 1998; Moranta et al., 2000; Machias et al., 2001; Pranovi et al., 2001; Sartor et al., 2001; Sanchez et al., 2004). However, research is still necessary to better understand the dynamics of catches and discards due to spatio-temporal changes in fishing effort (Piet and Jennings, 2005).

The aim of the present study is to detect, for the first time, the influence of different levels of fishing intensity (fishing closure, high and low fishing activity) on the catch composition, including both the retained and discarded fractions. The study was carried out in two Mediterranean areas, one in the Adriatic Sea (central Mediterranean) and the other in the Catalan Sea (western Mediterranean).

\section{MATERIAL AND METHODS}

\section{Fishing grounds}

The Adriatic fishing ground $\left(44^{\circ} 01^{\prime} \mathrm{N}-13^{\circ} 17^{\prime} \mathrm{E}\right)$ is located off the Marche Region, between 15 and 16 nautical miles from Fano harbour. The area, of about $160 \mathrm{~km}^{2}$, is characterized by sandy-muddy bottoms and by depths ranging from 50 to $55 \mathrm{~m}$. It is influenced by the discharges of the Metauro River.
The Fano trawl fleet exploits this area all year round, with seasonal variations that are due to the influence of weather conditions and the availability of resources. As in the entire northern Adriatic Sea, each year the Fano trawl fleet is subjected to a period of fishing closure for 30 to 45 days, usually in summer.

The Catalan fishing ground $\left(40^{\circ} 26^{\prime} \mathrm{N}-0^{\circ} 41^{\prime} \mathrm{E}\right)$ is located in an area of about $425 \mathrm{~km}^{2}$ situated in the south of Catalonia, where the fishing fleet of Sant Carles de la Ràpita operates at water depths of about 25 to $60 \mathrm{~m}$. The sea bottom is characterized by a very wide shelf (at some points over $65 \mathrm{~km}$ ). This area is influenced by the continental waters of the Ebro River (Demestre et al., 2000). Mud and clay with low percentages of sand are the predominant sediments and occupy a large part of the shelf. Sand predominates over mud in the sediments of the more coastal area (Guillén and Palanques, 1997). The area is heavily exploited by otter trawlers with different temporal fishing strategies. Every year, the fleet of Sant Carles de la Ràpita is subjected to a period of fishing closure of two months (July and August).

\section{Fisheries characterization}

Different sampling approaches were considered for collecting detailed information on the characteristics of the fishing fleets and fishing activity:

- Census of the fleet: number of vessels; data on overall length (OL), gross registered tonnage (GRT), gross tonnage (GT), engine power (HP), gear in use, license, fishing area, etc. were collected for each boat in order to update this information for the period covered by the study. In the Adriatic study area, a census of the Fano trawling fleet was performed at the end of 2002, data was collected both at the Ufficio Marittimo Locale of Fano and by interviewing the fishermen and the fisherman's associations. In the Catalan area, the fleet census for 2003 was obtained from the official information of the Fisherman's Association of Sant Carles de la Ràpita.

- Estimating fishing activity in the Adriatic Sea: 4 to 5 days of observations per month were performed in 2003 at the landing point by interviewing the skipper. Data on number, duration, position, depth of the hauls were collected for each boat. Further information was gathered at the auction to estimate the monthly fishing activity of the fleet 
(number of fishing days per month per vessel). In the Catalan area, data was collected between November 2002 and January 2004; the number of vessels at the fish auction were registered daily to determine the fishing activity (hours per month for each vessel working in the fishing ground).

Fishermen were interviewed to determine the periods of different fishing intensity more accurately in the two fishing grounds. All the data were standardized to fishing hours per $\mathrm{km}^{2}$.

\section{Catch composition and yields}

In both areas, the trawl catches were analyzed through observations on board commercial otter trawlers; vessels usually working in the fishing grounds studied were selected.

In the Adriatic area, two days of observations on board a commercial otter trawler $(\mathrm{OL}=17.6$; GT=34) were carried out bimonthly from February 2003 to January 2004; a total of 39 commercial hauls lasting from 2 to 3 hours was sampled.

In the Catalan fishing ground, sampling on board two otter trawlers (mean $\mathrm{OL}=16.8$; mean $\mathrm{GT}=41.1$ ) was carried out two to three days each month by two observers from November 2002 to December 2003. The average duration of the hauls was 2-3 hours. A total of 50 hauls was analyzed.

In both areas the vessels employed trawl nets with a stretched codend mesh size of $40 \mathrm{~mm}$. The species composition of both the retained and discarded fractions was recorded in each haul to the lowest taxonomic level possible. A subsample of the discard was taken when it was very large.

In this paper the term discard refers to the fraction of the catch thrown back into the sea, which is composed of commercial and non-commercial species, according to Alverson et al. (1994).

Data on biomass $(\mathrm{kg})$ per species were registered. Catch data of each haul were standardized to $\mathrm{kg}$ per fishing hour; mean values of the retained and discarded fractions were computed on a bimonthly basis in order to have the same temporal scale.

The retained fraction (retained catch/total catch) was calculated for each haul. This ratio was used by Alverson and Hughes (1996) to define the Ecological Use Efficiency (EUE) index.

The Kruskall-Wallis non-parametric ANOVA (Siegel and Castellan, 1988) was employed to test differences in the retained fraction of the high and low fishing intensity periods in each area.

\section{RESULTS}

\section{Fisheries characterization}

The fishing fleet located in Fano harbour consists of 131 vessels: 27 otter trawlers, 4 "rapido" (beam) trawlers, 43 artisanal fishery vessels, 7 vessels using pelagic longlines and 50 vessels with hydraulic dredges for clams. The fleet sector that exploits the studied fishing ground is represented by the otter trawl vessels. The 27 trawlers can be divided into three categories according to GT: large sized vessels (more than $100 \mathrm{GT}$ ), medium (30-100 GT) and small (less than $30 \mathrm{GT}$ ). Each category also differs in terms of mean engine power (410, 325 and $150 \mathrm{HP})$ and overall length $(27,20,12 \mathrm{~m})$. The trawl vessels of the Fano fleet normally fish four days a week, from Monday to Thursday, leaving the harbour at 4.00 a.m. and coming back at 3.00 a.m. the following day to land the catch. The medium and small trawlers usually make fishing trips of one day, while the large vessels (>100 GT) can remain out at sea for two consecutive days, depending on the weather conditions. The studied fishing ground is mostly exploited by the medium sized vessels all year round, and also by the large sized vessels, although less frequently. During the study period the fishing activity was characterized by a clear seasonal pattern (Fig. 1): A high exploitation rate was detected from January to June. Fishing intensity decreased in July when the low availability of demersal resources made it economically unprofitable to fish in the area. After the fishing closure (August-September), trawl activity was low in the studied fishing ground, and was concentrated near the coast (within 12 miles).

At the end of 2003 the Sant Carles de la Ràpita fishing fleet was composed of a total of 118 vessels:

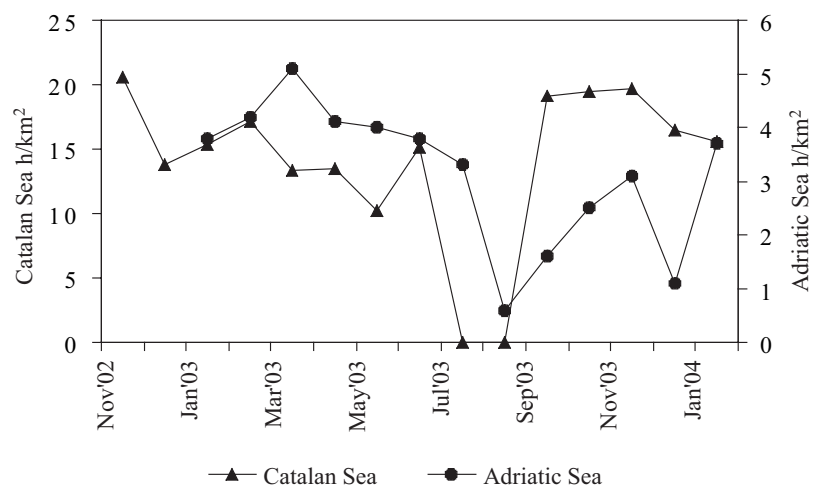

FIG. 1. - Annual evolution of fishing activity in the two fishing grounds studied. 
768 • P. SÁNCHEZ et al.

TABLE 1. - Catch composition in the two fishing grounds. $\mathrm{R}=$ species totally retained; $\mathrm{Rd}=$ species mainly retained (small sized or damaged specimens discarded); $\mathrm{rD}=$ species mainly discarded (large sized specimens retained); $\mathrm{D}=$ species totally discarded

\begin{tabular}{|c|c|c|c|c|c|}
\hline & Adriatic area & Catalan area & & Adriatic area & Catalan area \\
\hline CHONDRICHTHYES & & & Pagurus alatus & $\mathrm{D}$ & \\
\hline Mustelus sp. & $\mathrm{R}$ & & Pagurus excavatus & $\mathrm{D}$ & \\
\hline Raja brachyura & & $\mathrm{R}$ & Parapenaeus longirostris & $\mathrm{D}$ & \\
\hline Raja sp. & & $\mathrm{R}$ & Penaeus kerathurus & $\mathrm{R}$ & $\mathrm{R}$ \\
\hline OSTEICHTHYES & & & Plesionika sp. & & $\mathrm{Rd}$ \\
\hline Alosa fallax nilotica & $\mathrm{D}$ & $\mathrm{D}$ & Processa canaliculata & $\mathrm{D}$ & \\
\hline Antonogadus megalokynodon & $\mathrm{D}$ & & Scyllaris arcus & & $\mathrm{D}$ \\
\hline Arnoglossus laterna & $\mathrm{Rd}$ & & Solenocera membranacea & $\mathrm{rD}$ & \\
\hline Aspitrigla cuculus & & $\mathrm{Rd}$ & Squilla mantis & $\mathrm{Rd}$ & $\mathrm{Rd}$ \\
\hline Blenius ocellaris & & $\mathrm{D}$ & CEPHALOPODA & & \\
\hline Boops boops & $\mathrm{rD}$ & $\mathrm{rD}$ & Alloteuthis sp. & $\mathrm{Rd}$ & $\mathrm{R}$ \\
\hline Callionymus lyra & & $\mathrm{D}$ & Eledone cirrhosa & & $\mathrm{Rd}$ \\
\hline Cepola rubescens & $\mathrm{Rd}$ & $\mathrm{Rd}$ & Eledone moschata & $\mathrm{R}$ & \\
\hline Citharus linguatula & $\mathrm{Rd}$ & $\mathrm{Rd}$ & Illex coindetii & $\mathrm{Rd}$ & $\mathrm{R}$ \\
\hline Conger conger & $\mathrm{R}$ & $\mathrm{Rd}$ & Loligo vulgaris & $\mathrm{Rd}$ & $\mathrm{Rd}$ \\
\hline Dactylopterus volitans & & $\mathrm{D}$ & Octopus vulgaris & $\mathrm{R}$ & $\mathrm{R}$ \\
\hline Deltentosteus quadrimaculatus & $\mathrm{D}$ & & Sepia elegans & $\mathrm{rD}$ & \\
\hline Dicentrarchus labrax & $\mathrm{R}$ & $\mathrm{R}$ & Sepia officinalis & $\mathrm{R}$ & $\mathrm{R}$ \\
\hline Diplodus annularis & $\mathrm{Rd}$ & $\mathrm{rD}$ & Sepietta oweniana & $\mathrm{rD}$ & \\
\hline Diplodus sargus & & $\mathrm{Rd}$ & Sepiola intermedia & $\mathrm{D}$ & \\
\hline Diplodus vulgaris & & $\mathrm{rD}$ & BIVALVIA & & \\
\hline Engraulis encrasicholus & $\mathrm{Rd}$ & $\mathrm{Rd}$ & Acanthocardia echinata & & $\mathrm{D}$ \\
\hline Gobius geniporus & $\mathrm{D}$ & & Acanthocardia paucicostata & & $\mathrm{D}$ \\
\hline Gobius niger & $\mathrm{Rd}$ & $\mathrm{Rd}$ & Anadara demiri & $\mathrm{D}$ & \\
\hline Lepidorhombus boscii & & $\mathrm{R}$ & Anadara inaequivalvis & & $\mathrm{D}$ \\
\hline Lepidotrigla cavillone & $\mathrm{rD}$ & & Azorinus chamasolen & $\mathrm{D}$ & \\
\hline Lesueurigobius friesii & $\mathrm{D}$ & & Callista chione & & $\mathrm{D}$ \\
\hline Lesueurigobius suerii & $\mathrm{D}$ & & Chlamys glabra & & $\mathrm{D}$ \\
\hline Lophius spp. & $\mathrm{Rd}$ & $\mathrm{Rd}$ & Corbula gibba & $\mathrm{D}$ & \\
\hline Merlangius merlangus euxinus & $\mathrm{Rd}$ & & Mytilus galloprovincialis & $\mathrm{D}$ & \\
\hline Merluccius merluccius & $\mathrm{Rd}$ & $\mathrm{Rd}$ & Nucula sp & & $\mathrm{D}$ \\
\hline Microchirus variegatus & $\mathrm{D}$ & & Ostrea edulis & $\mathrm{D}$ & \\
\hline Mullus barbatus & $\mathrm{Rd}$ & $\mathrm{Rd}$ & Pecten jacobeus & & $\mathrm{Rd}$ \\
\hline Mullus surmuletus & $\mathrm{R}$ & $\mathrm{Rd}$ & Tracia pubescens & $\mathrm{D}$ & \\
\hline Pagellus acarne & & $\mathrm{rD}$ & Venus пих & & $\mathrm{D}$ \\
\hline Pagellus erythrinus & $\mathrm{Rd}$ & $\mathrm{rD}$ & GASTROPODA & & \\
\hline Pagrus pagrus & & $\mathrm{R}$ & Aplisya sp. & & $\mathrm{D}$ \\
\hline Pomatomus saltatrix & & $\mathrm{R}$ & Aporrhais pespelecani & $\mathrm{D}$ & $\mathrm{D}$ \\
\hline Psetta maxima & & $\mathrm{R}$ & Armina tigrina & $\mathrm{D}$ & \\
\hline Sardina pilchardus & $\mathrm{R} / \mathrm{D}$ & $\mathrm{rD}$ & Bolinus brandaris & & $\mathrm{Rd}$ \\
\hline Sardinella aurita & $\mathrm{D}$ & $\mathrm{D}$ & Calliostoma granulatum & $\mathrm{D}$ & $\mathrm{D}$ \\
\hline Scomber scombrus & $\mathrm{Rd}$ & $\mathrm{rD}$ & Cancellaria cancellata & & $\mathrm{D}$ \\
\hline Scophthalmus rhombus & $\mathrm{D}$ & $\mathrm{R}$ & Epitonium clathrus & & $\mathrm{D}$ \\
\hline Scorpaena notata & $\mathrm{Rd}$ & $\mathrm{Rd}$ & Hexaples trunculus & & $\mathrm{Rd}$ \\
\hline Seriola dumerili & & $\mathrm{R}$ & Nassarius sp. & & $\mathrm{D}$ \\
\hline Serranus hepatus & $\mathrm{D}$ & & Natica fusca & & $\mathrm{D}$ \\
\hline Sphyraena sphyraena & D & $\mathrm{rD}$ & Natica hebraea & & $\mathrm{D}$ \\
\hline Solea vulgaris vulgaris & $\mathrm{R}$ & $\mathrm{R}$ & Turritella communis & $\mathrm{D}$ & $\mathrm{D}$ \\
\hline Sparus aurata & & $\mathrm{R}$ & ECHINODERMATA & & \\
\hline Spicara flexuosa & $\mathrm{rD}$ & & Anthedon sp. & & $\mathrm{D}$ \\
\hline Spicara smaris & & $\mathrm{D}$ & Astropecten bispinosus & $\mathrm{D}$ & \\
\hline Sprattus sprattus & $\mathrm{D}$ & & Astropecten i. pentacanthus & $\mathrm{D}$ & \\
\hline Trachinus araneus & & $\mathrm{Rd}$ & Astropecten sp. & & $\mathrm{D}$ \\
\hline Trachurus $m$. mediterraneus & $\mathrm{rD}$ & & Echinaster sepositus & $\mathrm{D}$ & $\mathrm{D}$ \\
\hline Trachurus picturatus & $\mathrm{D}$ & & Echinus acutus & & $\mathrm{D}$ \\
\hline Trachurus trachurus & $\mathrm{rD}$ & $\mathrm{Rd}$ & Holothuria tubulosa & $\mathrm{D}$ & \\
\hline Trigla lucerna & $\mathrm{Rd}$ & $\mathrm{Rd}$ & Holoturoidea unidentified & $\mathrm{D}$ & \\
\hline Trisopterus minutus capelanus & $\mathrm{Rd}$ & $\mathrm{Rd}$ & Marthasterias glacialis & $\mathrm{D}$ & \\
\hline Umbrina cirrosa & & $\mathrm{R}$ & Ocnus planci & $\mathrm{D}$ & \\
\hline Uranoscopus scaber & $\mathrm{R}$ & $\mathrm{Rd}$ & Phyllophorus urna & $\mathrm{D}$ & \\
\hline Zeus faber & $\mathrm{Rd}$ & $\mathrm{Rd}$ & Schizaster canaliferus & $\mathrm{D}$ & $\mathrm{D}$ \\
\hline CRUSTACEA & & & Stichopus regalis & $\mathrm{D}$ & $\mathrm{Rd}$ \\
\hline Alpheus glaber & $\mathrm{D}$ & & Trachythyone elongata & $\mathrm{D}$ & \\
\hline Calappa granulata & & $\mathrm{Rd}$ & Trachythyone sp. & & $\mathrm{D}$ \\
\hline Dardanus arrosor & & $\mathrm{D}$ & Trachythyone tergestina & $\mathrm{D}$ & \\
\hline Dromia personata & $\mathrm{D}$ & $\mathrm{D}$ & CNIDARIA & & \\
\hline Goneplax rhomboides & $\mathrm{D}$ & $\mathrm{D}$ & Alcyonium acaule & $\mathrm{D}$ & \\
\hline Homarus gammarus & & $\mathrm{R}$ & Alcyonium palmatum & $\mathrm{D}$ & $\mathrm{D}$ \\
\hline Liocarcinus depurator & $\mathrm{rD}$ & $\mathrm{rD}$ & Calliactis parasitica & $\mathrm{D}$ & \\
\hline Macropodia sp. & $\mathrm{D}$ & & Chrysaora hysoscella & & $\mathrm{D}$ \\
\hline Maja squinado & $\mathrm{R}$ & & Hydrozoa unidentified & $\mathrm{D}$ & \\
\hline Medorippe lanata & $\mathrm{D}$ & $\mathrm{D}$ & Virgularia mirabilis & $\mathrm{D}$ & \\
\hline Nephrops norvegicus & $\mathrm{R}$ & $\mathrm{Rd}$ & & & \\
\hline
\end{tabular}


59 otter trawlers, 24 beam trawlers, 15 artisanal vessels using trammel nets, 14 longlines, 4 boat dredges and 2 other artisanal boats. The only fishing gear employed in the study area was otter trawling. The majority of vessels belong to two categories: small sized vessels $(<30$ GT) with an average engine power of 110 HPA and an average overall length of $13 \mathrm{~m}$, and medium sized vessels (between 30 and 100 GT) with average values of engine power and overall length of $315 \mathrm{HPA}$ and $20 \mathrm{~m}$ respectively. Only two vessels fall into the large size category (>100 GT). The fishing activity of the trawl fleet is carried out daily from Monday to Friday from 6:30 AM to 4:30 PM. This involves an effective fishing time of approximately 8 hours per day. Each vessel returns every day to the harbour and sells the catch at the auction. The small vessels work throughout the year in the coastal fishing ground. The big vessels do not often work in this fishing ground. The medium sized vessels work in the coastal fishing ground with different intensities according to the seasons. According to the data collected in this study, a period of low fishing intensity can be defined from March to June followed by a two month cessation (July-August). After the closure most of the fleet worked in this area (Fig. 1), and therefore the period from September to February was considered to be high fishing intensity, which was especially evident from September to November. The beginning and the end of the period of low fishing intensity vary quite a lot according to the year and depending on the recruitment of commercial species.

\section{Catch composition and yields}

Totals of 92 and 88 species belonging to eight major taxa were collected during the onboard obser- vations in the Adriatic and Catalan fishing grounds respectively (Tables 1 and 2).

The species composition of the retained and discarded catches showed close agreement between the two areas. In the Adriatic fishing ground the catch of 13 species was totally retained, while that of 30 species was partially retained and that of 49 species totally discarded. In the Catalan fishing ground 18 species were totally retained, 35 were partially retained and 35 totally discarded.

The most significant group in the catches was represented by Osteichthyes, which accounted for 40 species caught in both areas. More than $50 \%$ of these species were commercially important. Merluccius merluccius and Mullus barbatus represented the most relevant fraction of the landings (retained species) in both fishing grounds, showing very low discard rates.

Crustaceans were the second most important group, which was mainly represented by the mantis shrimp, Squilla mantis, that was largely retained, and the swimming crab Liocarcinus depurator, characterized by large discard rates. Cephalopods were mainly represented by Loligo vulgaris, Octopus vulgaris and Sepia officinalis, which showed low or null discard rates.

Bivalves, gastropods and echinoderms were totally discarded in the Adriatic Sea, while in the Catalan Sea some species were partially retained, such as the bivalve Pecten jacobaeus, the gastropods Bolinus brandaris and Hexaplex trunculus and the holothuroid Stichopus regalis. Cnidarians have no commercial value in either area.

The proportion of retained and discarded biomass varied throughout the study period in both areas (Fig. 2). The commercial yields were highest after the fishing closure and progressively

TABLE 2. - Catch composition per taxon in the two investigated fishing grounds. $\mathrm{R}=$ species totally retained; $\mathrm{R} / \mathrm{D}=$ species partially retained and discarded; $\mathrm{D}=$ species totally discarded.

\begin{tabular}{|c|c|c|c|c|c|c|c|c|}
\hline & \multicolumn{4}{|c|}{$\begin{array}{c}\text { Adriatic area } \\
\text { Number of species/taxa }\end{array}$} & \multicolumn{4}{|c|}{$\begin{array}{c}\text { Catalan area } \\
\text { Number of species/taxa }\end{array}$} \\
\hline & Caught & $\mathrm{R}$ & $\mathrm{R} / \mathrm{D}$ & $\mathrm{D}$ & Caught & $\mathrm{R}$ & $\mathrm{R} / \mathrm{D}$ & $\mathrm{D}$ \\
\hline Chondrichthyes & 1 & 1 & & & 2 & 2 & & \\
\hline Osteichthyes & 40 & 6 & 22 & 12 & 40 & 10 & 24 & 6 \\
\hline Crustacea & 15 & 3 & 3 & 9 & 12 & 2 & 5 & 5 \\
\hline Cephalopoda & 9 & 3 & 5 & 1 & 6 & 4 & 2 & \\
\hline Bivalvia & 6 & & & 6 & 8 & & 1 & 7 \\
\hline Gastropoda & 4 & & & 4 & 11 & & 2 & 9 \\
\hline Echinodermata & 12 & & & 12 & 7 & & 1 & 6 \\
\hline Cnidaria & 5 & & & 5 & 2 & & & 2 \\
\hline Total & 92 & 13 & 30 & 49 & 88 & 18 & 35 & 35 \\
\hline
\end{tabular}



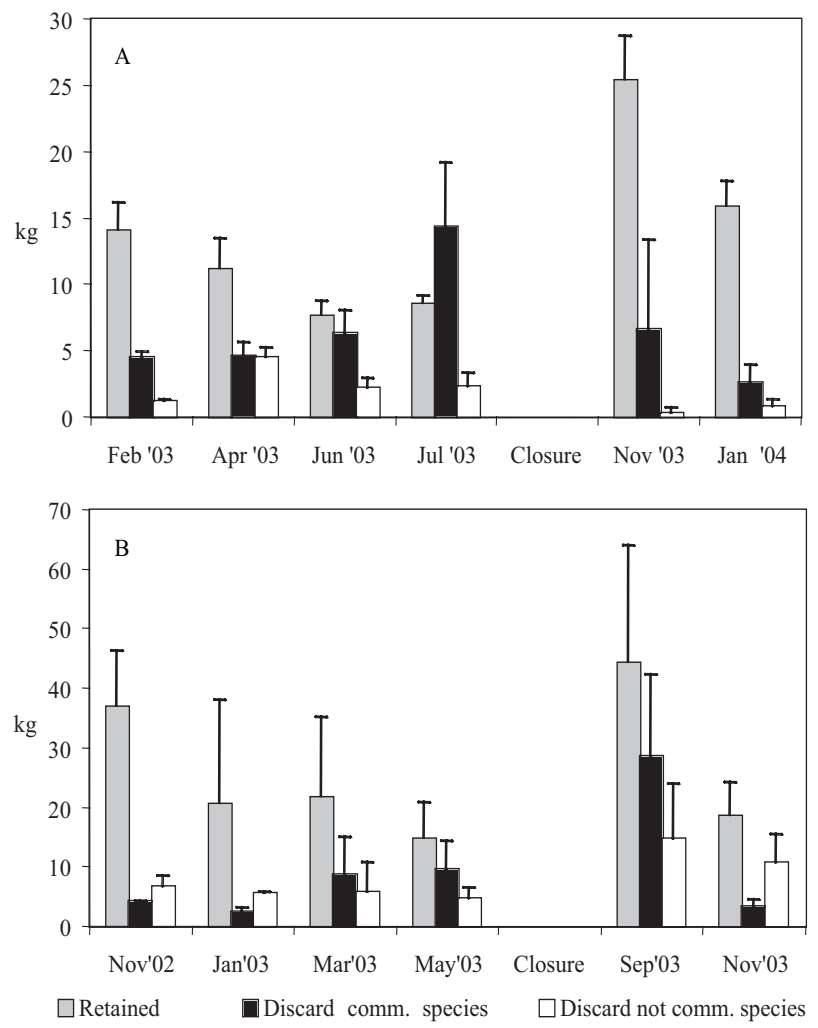

FIG. 2. - Yield composition observed in the two fishing grounds. A: Adriatic Sea; B: Catalan Sea. decreased over the following months. The minimum values were observed in the months before the fishing closure.

The discard of commercial species was higher than the discard of non-commercial species throughout the observation period in both areas, except from November to January in the Catalan area.

In both fishing grounds the retained fraction was slightly higher in the high fishing intensity periods than in the low intensity ones (Adriatic Sea: 0.613 vs 0.524; Catalan Sea: 0.597 vs 0.539, Table 3), even though the Kruskall Wallis test only revealed significant differences $(p<0.05)$ for the Adriatic Sea.

In terms of the catches of the different taxonomic groups, in the Adriatic fishing ground the percentage of retained bony fishes was higher in the high intensity period than in the low period; while in the Catalan Sea the retained fraction of cephalopods (mainly O. vulgaris) in the high fishing period was higher than in the low period (Table 3 ). The other groups did not show relevant differences between the periods of high and low fishing intensity, even though in general, the discarded fraction was higher during the periods of low fishing activity for each group.

TABLE 3. - Retained and discarded catches of the main taxa observed in the two fishing grounds in the periods of high and low fishing intensity. Data are expressed in $\mathrm{kg} /$ fishing hour and the relative percentages with respect to the total catch $(*=<0.1)$.

\begin{tabular}{|c|c|c|c|c|c|c|c|c|c|c|c|c|}
\hline & \multirow[b]{2}{*}{ Retained } & \multirow{2}{*}{\multicolumn{3}{|c|}{ High fishing intensity }} & \multicolumn{3}{|c|}{ Adriatic fishing ground } & \multicolumn{3}{|c|}{ Low fishing intensity } & \multirow[b]{2}{*}{ Total } & \multirow[b]{2}{*}{$(\%)$} \\
\hline & & & & & Total & $(\%)$ & Retained & $\begin{array}{l}\mathrm{Lc} \\
(\%)\end{array}$ & $\begin{array}{l}\text { w fishing in } \\
\text { Discarded }\end{array}$ & $\begin{array}{r}\text { ensity } \\
(\%)\end{array}$ & & \\
\hline Osteychtyes & 9.041 & 45.3 & 3.321 & 16.6 & 12.362 & 62.0 & 8.501 & 30.3 & 5.942 & 21.2 & 14.443 & 51.4 \\
\hline Chondrychtyes & & & 0.008 & $*$ & 0.008 & * & 0.221 & 0.8 & & & 0.069 & 0.2 \\
\hline Cephalopoda & 0.875 & 4.4 & 0.080 & 0.4 & 0.955 & 4.8 & 0.815 & 2.9 & 0.091 & 0.3 & 0.906 & 3.2 \\
\hline Crustacea & 2.243 & 11.2 & 2.714 & 13.6 & 4.957 & 24.8 & 5.273 & 18.8 & 4.854 & 17.3 & 10.127 & 36.1 \\
\hline Bivalvia & & & 0.154 & 0.8 & 0.154 & 0.8 & & & 0.221 & 0.8 & 0.221 & 0.8 \\
\hline Gastropoda & & & 0.485 & 2.4 & 0.485 & 2.4 & & & 0.631 & 1.7 & 0.631 & 1.7 \\
\hline Echinodermata & & & 0.867 & 4.3 & 0.867 & 4.3 & & & 1.685 & 6.0 & 1.685 & 6.0 \\
\hline Cnidaria & & & 0.044 & 0.2 & 0.044 & 0.2 & & & 0.051 & * & 0.051 & $*$ \\
\hline Others & & & 0.121 & 0.6 & 0.121 & 0.6 & & & 0.096 & 0.3 & 0.096 & 0.3 \\
\hline \multirow{3}{*}{$\begin{array}{l}\text { Total } \\
\text { Retained fraction }\end{array}$} & 12.159 & 60.9 & 7.794 & 39.1 & 19.953 & 100.0 & 14.810 & 52.8 & \multicolumn{2}{|c|}{$\begin{array}{c}52.80_{0.524( \pm 0.082)} \\
0.871 .8\end{array}$} & 28.074 & 100.0 \\
\hline & & \multirow{2}{*}{\multicolumn{3}{|c|}{ High fishing effort }} & \multicolumn{3}{|c|}{ Catalan fishing ground } & & & \\
\hline & Retained & & & & Total & $(\%)$ & Retained & & & & Total & $(\%)$ \\
\hline Osteychtyes & 17.427 & 28.5 & 14.645 & 23.9 & 32.072 & 52.4 & 9.272 & 29.9 & 6.193 & 19.9 & 15.466 & 49.8 \\
\hline Chondrychtyes & 0.135 & 0.2 & & & 0.135 & 0.2 & 0.143 & 0.5 & & & 0.143 & 0.5 \\
\hline Cephalopoda & 6.710 & 11.0 & 0.024 & * & 6.733 & 11.0 & 1.203 & 3.9 & 0.029 & 0.1 & 1.232 & 4.0 \\
\hline Crustacea & 12.050 & 19.7 & 4.053 & 6.6 & 16.103 & 26.3 & 5.835 & 18.8 & 6.248 & 20.1 & 12.083 & 38.9 \\
\hline Bivalvia & 0.004 & * & 2.118 & 3.5 & 2.122 & 3.5 & 0.015 & $*$ & 0.506 & 1.6 & 0.521 & 1.7 \\
\hline Gastropoda & 0.214 & 0.4 & 0.218 & 0.4 & 0.433 & 0.7 & 0.259 & 0.8 & 0.531 & 1.7 & 0.790 & 2.5 \\
\hline Echinodermata & 0.002 & $*$ & 2.552 & 4.2 & 2.553 & 4.2 & & & 0.768 & 2.5 & 0.768 & 2.5 \\
\hline Cnidaria & & & 1.008 & 1.6 & 1.008 & 1.6 & & & 0.051 & 0.2 & 0.051 & 0.2 \\
\hline Total & 36.542 & 59.8 & 24.618 & 40.2 & 61.159 & 100.0 & 16.727 & 53.9 & 14.326 & 46.1 & 31.054 & 100.0 \\
\hline Retained fraction & & & $97( \pm 0$. & & & & & & & & & \\
\hline
\end{tabular}



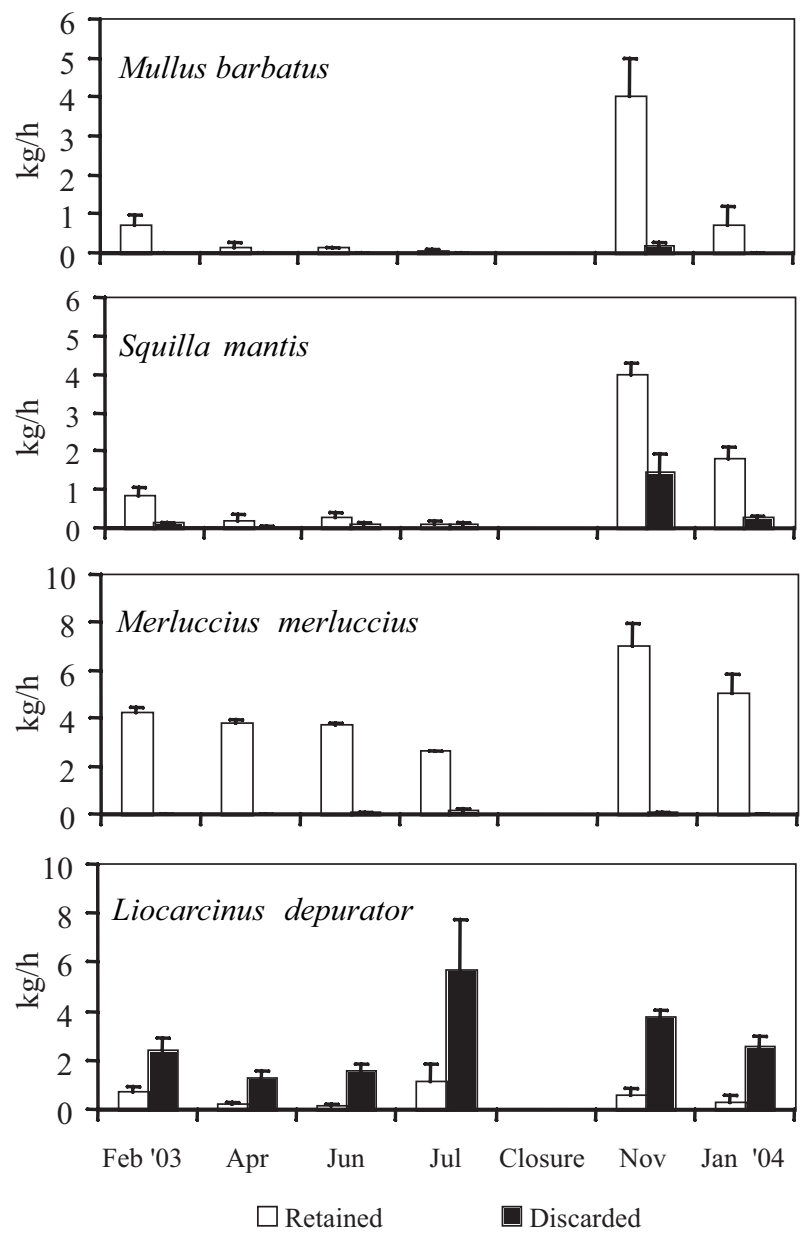

FIG. 3. - Adriatic fishing ground: retained and discarded catch of some species.

\section{Catch of the main exploited species}

The target species in the two fishing grounds show different discard levels.

In both areas, Mullus barbatus had very low discard rates and the catches were highest after the fishing closure (Figs. 3 and 4). In both fishing grounds Squilla mantis was one of the most significant species in terms of biomass; the yields showed a clear seasonality, with a peak in November. Discard rates of this species were always low (Figs. 3 and 4).

Catches of Merluccius merluccius in the Adriatic Sea were substantially constant throughout the observed period and the species showed very low discard rates. The retained fraction of Loligo vulgaris in the Catalan fishing ground was always greater than the discarded one which was consistent only after the closure (Fig. 4).

In the Adriatic fishing ground Liocarcinus depurator represented one of the few commercial species
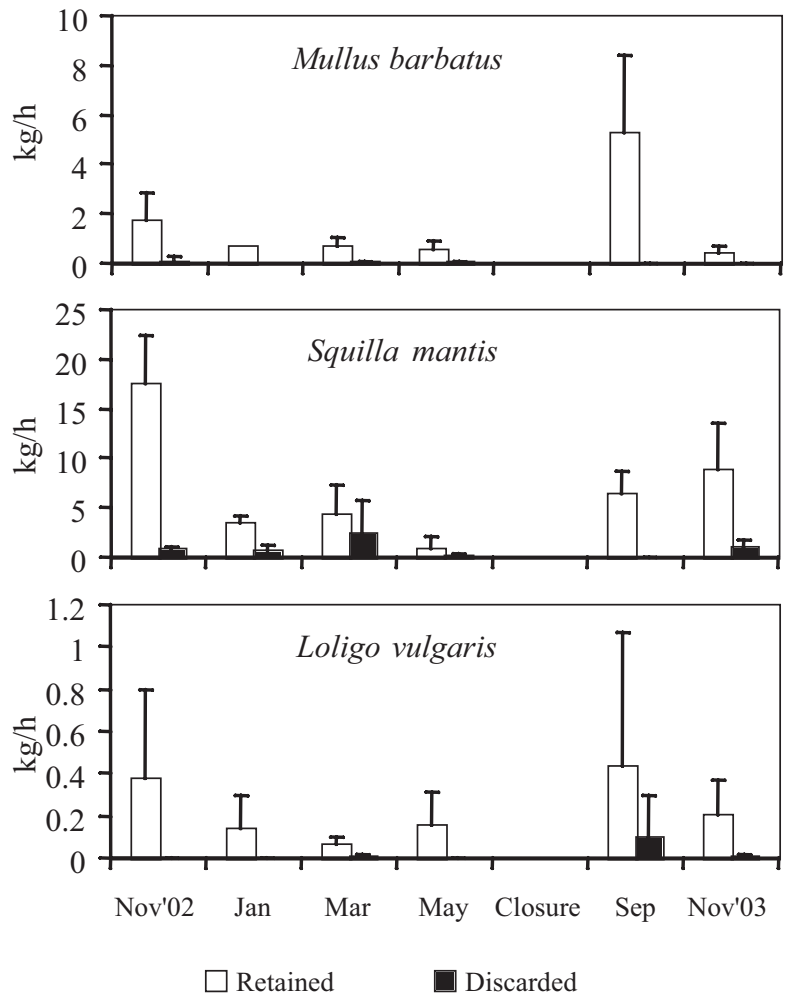

FIG. 4. - Catalan fishing ground: retained and discarded catch of some species.

characterized by a consistent discard, which was often higher than the retained fraction (Fig. 3).

\section{DISCUSSION}

In the Mediterranean, although trawling exploitation is directed at a restricted number of target species, the total landing and its economic value are due also to several species belonging to the so called "retained by-catch"; for this reason the Mediterranean trawl fishery has been classified as multispecific (Caddy, 1993).

In spite of this, a consistent percentage of the bottom trawl catches is routinely discarded in the Mediterranean. Stergiou et al. (1998) estimated that $45 \%$ of the total catch was discarded in 1995 by the Greek trawl fleet.

Recent studies have estimated the amount of trawling discards as 20 to $50 \%$ of the biomass caught in different Mediterranean areas (Moranta et al., 2000; Machias et al., 2001; D'Onghia et al., 2003; Sartor et al., 2003; Sanchez et al., 2004). About half of the discarded biomass is composed of species of commercial interest and the rest is made up of species without economic value. The amount 
of discard varied greatly depending on the areas and/or fishing grounds considered: in general, discard rates were higher on the shallower bottoms (up to $50-60 \%$ of the total biomass caught may be discarded) than in the deeper waters, such as the Norway lobster and red shrimp fishing grounds.

Even though small areas and a restricted portion of the fleets were considered in the present study, the results obtained (39-48\% discard) fall within the previously mentioned range. In the two fishing grounds studied the total catches were characterized by high numbers of species, especially the discarded portion. This is mainly due to the species diversity of the exploited fish assemblages and the low selectivity of the gear. Discard of commercial species was mostly composed of low commercial value species, such as L. depurator, which has low and inconstant market demand. Discard of target species was low or practically absent in the case of M. merluccius and M. barbatus. This is because in the two fishing grounds the size composition of the catches of both species was made up of specimens larger than their minimum landing size. In other Mediterranean areas the discard rates of target species may reach high levels. Sartor et al. (2001) reported that about $30 \%$ of the M. merluccius specimens caught in the northern Tyrrhenian Sea were discarded, especially in summer when there are large amounts of juveniles.

Taking into account the similar characteristics of the two fishing grounds studied, in terms of depth, bottom features and species assemblages, it is worth noting the similar species composition of the retained catches. This highlights a similar pattern in commercialization and market demand, which is a result of a common cultural and historic background, and involves a large number of marketed species. This is a common characteristic of all Mediterranean fisheries, which distinguishes them from fisheries of other areas, such as the Atlantic Ocean.

The present study focused on detecting the influence of different levels of fishing intensity (fishing closure, high and low fishing activity) on the catch composition. Currently, periodic fishing closure is one of the most important management measures for regulating fishing effort of trawling in the Mediterranean. It has been in force in almost all the European Mediterranean countries for at least 15 years. Closure duration differs in the various countries, lasting for about 1.5 months in Italy, 2 months in Spain and 4 months in Greece.
The two areas studied were characterized by different levels of effort throughout the year, even though the differences between high and low fishing intensity were not so pronounced. However, the periods of fishing activity were different in the two fishing grounds. The main difference was that in the Adriatic fishing ground, fishing closure was followed by a period of low fishing intensity, while the opposite situation occurred in the Catalan study area. This aspect is due to the fishing strategies of the two fleets, mainly in relation to the exploitation of other fishing grounds and target species throughout the year.

In terms of catch composition, the present study shows that the retained fraction was slightly higher in both areas in the high fishing intensity period. This could indicate that the resources are exploited more efficiently in the high fishing intensity period. No seasonal effect in the overall community can be taken into account because high and low fishing intensity periods occurred in different seasons in the two areas (spring in the Catalan Sea and autumn in the Adriatic Sea).

In both areas the maximum yields were registered after fishing closure and then the retained yields progressively decreased. This is a rather common feature that has been observed in other Mediterranean areas where fishing closure is in force, especially if its duration is consistent (Machias et al., 2001).

Even so, the increase in yields of some commercial species after the fishing closure could be due not only to the previous fishing cessation, but also to biological factors of the exploited resources. In both areas the increase in the yields after fishing closure is also a consequence of the recruitment of some species, such as $M$. barbatus in both areas (Demestre et al., 1997; Martin et al., 1999) and $O$. vulgaris in the Catalan Sea (Tsangridis et al., 2002).

In addition, it is difficult to find clear mid to long term effects due to this measure. Preliminary results of an experimental study performed in the same areas suggest that the applied closure periods are not long enough to obtain a clear recovery of the benthic communities (De Juan et al., 2005).

The true efficacy of fishing closure is still subject to a large debate between fishery scientists, managers and stakeholders. Alternative measures, such as spatio-temporal closures, have been proposed to complement fishing closure. The closure of restricted areas for several years, such as the Gulf of 
Castellammare (southern Tyrrhenian Sea), produced a consistent increase in biomass and mean size of many species (Pipitone et al., 2000). Moreover, it has recently been proposed to close eleven fishing areas in Italy.

\section{ACKNOWLEDGEMENTS}

The Authors would like to express their gratitude to the crew of the Catalan and Adriatic otter trawlers Vicent, Guadalupe Dos and Alì, as well as the members of the Confraria de Pescadors of Sant Carles de la Ràpita and the Associazione Produttori Pesca Adriatica of Fano for their kindness and support and Ms. C. Stonehouse for reviewing the English text. This work is part of the project RESPONSE (Q5RS2002-00787), funded by the European Commission.

\section{REFERENCES}

Alverson, D.L. and S.E. Hughes. - 1996. By-catch: from emotion to effective natural resource management. Rev. Fish. Biol. and Fish., 6: 443-462.

Alverson, D.L., M.H. Freeberg, S.A. Murawski and J.G. Pope. 1994. A global assessment of fisheries by catch and discards. FAO Fish. Tech. Pap., 339: 233 pp.

Bas, C. - 2005. Fishery research: current approches, tensions and emerging aspects. The future and how to approch it. Sci. Mar. 69(suppl. 1): 139-156.

Caddy, J.F. - 1993. Some future perspectives for assessment and management of Mediterranean fisheries. Sci. Mar., 57: 121-130.

Carbonell, A., P. Martín, S. De Ranieri and WEDIS team. - 1998. Discards of the western Mediterranean trawl fleets. Rapp. Comm. int. Mer Médit., 35: 292-293.

De Juan, S., M. Demestre, P. Sanchez, P. Sartor, A. Ligas, A. De Biasi, A. Palanques, L. Recasens and J. Cartes. - 2005. Seasonal area closure in two Mediterranean trawl fishing grounds: consequences on epibenthic fauna. ASLO Abstract Book, 39.

Demestre, M., M. Sbrana, F. Alvarez and P. Sánchez. - 1997. Analysis of the interaction of fishing gear in Mullus barbatus fisheries of the Western Mediterranean. J. Appl. Ichthyol., 13: 49-56

Demestre, M., P. Sánchez and P. Abelló. - 2000. Demersal fish assemblages of the continental shelf and upper slope of the Catalan coast, NW Mediterranean. J. Mar. Biol. Ass. UK, 80: 981-988.

D’Onghia G., R. Carlucci, P. Maiorano and M. Panza. - 2003. Discards from deep-water bottom trawling in the eastern-central Mediterranaean Sea and effects of mesh size changes. $J$. Northw. Atl. Fish. Sci., 31: 245-262.

Greenstreet S.P.R. and S. I. Rogers. - 2006. Indicators of the health of the North Sea fish community: identificatifying reference levels for an ecosystem approach to management. ICES J. Mar. Sci.,63: 573-593.

Guillén, J. and A. Palanques. - 1997. A shoreface zonation in the Ebro Delta based on grain size distribution. J. Coast. Res., 13: 867-878.

Jennings, S. and M.J. Kaiser. - 1998. The effects of fishing on marine ecosystems. Adv. Mar. Biol., 34: 201-352.

Kaiser, M.J. and S.J. De Groot (eds). - 1999. Effects of Fishing on Non-target Species and Habitats: Biological, Conservation and Socio-economic Issues. Blackwell Science, Oxford (UK).

Kelleher, K. - 2005. Discards in the world's marina fisheries. An update. FAO Fish. Tech. Pap., 470.

Machias, A., V. Vassilopoulou, D. Vatsos, P. Bekas, A. Kallianiotis, C. Papaconstantinou and N. Tsimenides. - 2001. Bottom trawl discards in the northeastern Mediterranean Sea. Fish.Res., 53: 181-195.

Martin, P., P. Sartor and M. Garcia-Rodriguez. - 1999. Exploitation patterns of the European hake Merluccius merluccius, red mullet Mullus barbatus and striped red mullet Mullus surmuletus in the western Mediterranean. J. Appl. Ichthyol., 15: 24-28.

Moranta, J., E. Massuti and B. Morales-Nin. - 2000. Fish catch composition of the deep-sea decapod crustacean fisheries in the Balearic Islands (western Mediterranean). Fish. Res., 45: 253-264.

Piet, G.J. and S. Jennings. - 2005. Response of potential fish community indicators to fishing. ICES J. Mar. SCi., 62: 214-225.

Pipitone, C., F. Badalamenti, G. D'Anna and B. Patti. - 2000. Fish biomass increase after a four-year trawl ban in the Gulf of Castellammare (NW Sicily, Mediterranean Sea). Fish. Res., 48: 23-30.

Pranovi, F., S. Raicevich, G. Franceschini, P. Torricelli and O. Giovanarvi. - 2001: Discard analysis and damage to non-target species in the "rapido" trawl fishery. Mar. Biol., 139: 863-875.

Rice, J. and H. Gislason. - 1996. Patterns of change in the size spectra of numbers and diversity of the North Sea fish assemblage, as reflected in surveys and models. ICES J. Mar. Sci., 53: $1214-1225$.

Rochet, M.J., I. Péronnet and V.M. Trenkel. - 2002. An analysis of discards from the French trawler fleet in the Celtic Sea. ICES J. Mar. Sci., 59: 538-552.

Sanchez, P., M. Demestre and P. Martín. - 2004. Characterization of the discards generated by bottom trawling in the Northwestern Mediterranean. Fish. Res., 67: 71-80

Sartor P., M. Sartini, B. Reale AND M. Sbrana. - 2001. Analysis of the discard practices in the Merluccius merluccius (L. 1758) bottom trawl fishery of the northern Tyrrhenian Sea. Biol. Mar. Medit. 8: 771-774.

Sartor P., M. Sbrana, B. Reale and P. Belcari. - 2003. Impact of the deep sea trawl fishery on demersal communities of the northern Tyrrhenian Sea- (Western Mediterranean). J. Northw. Atl. Fish. Sci., 31: 1-10

Siegel S. and N.J. Castellan. - 1988. Nonparametric Statistics for the Behavioural Sciences. New York: McGraw-Hill.

Stergiou K.I., A. Economou, C. Papaconstantinou, N. Tsimenides and S. Kavadas. - 1998. Estimates of discard in the Hellenic commercial trawl fishery. Rapp. Comm. Int. Mer Médit., 35: 490-491

Tsangridis A., P. Sánchez and D. Ioannidou. - 2002. Exploitation patterns of Octopus vulgaris in two Mediterranean areas. Sci. Mar., 66: 59-68.

Scient. ed.: A. Guerra.

Received March 15, 2007. Accepted October 19, 2007.

Published online November 9, 2007 